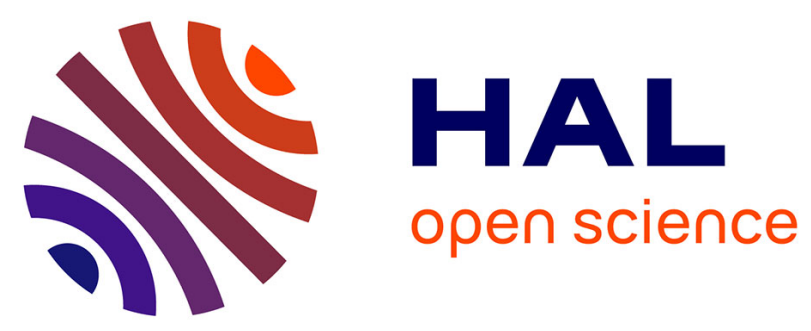

\title{
Mutational Spectrum in Holoprosencephaly Shows That FGF is a New Major Signaling Pathway
}

Christèle Dubourg, Wilfrid Carré, Houda Hamdi-Rozé, Charlotte Mouden, Joëlle Roume, Benmansour Abdelmajid, Daniel Amram, Clarisse Baumann, Nicolas Chassaing, Christine Coubes, et al.

\section{To cite this version:}

Christèle Dubourg, Wilfrid Carré, Houda Hamdi-Rozé, Charlotte Mouden, Joëlle Roume, et al.. Mutational Spectrum in Holoprosencephaly Shows That FGF is a New Major Signaling Pathway. Human Mutation, 2016, 37 (12), pp.1329-1339. 10.1002/humu.23038 . hal-01439363

\section{HAL Id: hal-01439363 \\ https://hal-univ-rennes1.archives-ouvertes.fr/hal-01439363}

Submitted on 28 Mar 2018

HAL is a multi-disciplinary open access archive for the deposit and dissemination of scientific research documents, whether they are published or not. The documents may come from teaching and research institutions in France or abroad, or from public or private research centers.
L'archive ouverte pluridisciplinaire HAL, est destinée au dépôt et à la diffusion de documents scientifiques de niveau recherche, publiés ou non, émanant des établissements d'enseignement et de recherche français ou étrangers, des laboratoires publics ou privés. 


\section{Mutational spectrum in holoprosencephaly shows that FGF is a new major signaling pathway}

Corresponding author: Dr Christèle Dubourg, Service de Génétique Moléculaire et Génomique, CHU Pontchaillou, 2 rue Henri Le Guilloux, F-35033 Rennes Cedex, France ; christele.dubourg@chu-rennes.fr; phone number 33299289829.

Christèle Dubourg ${ }^{1,2}$, Wilfrid Carré ${ }^{1,2}$, Houda Hamdi-Rozé ${ }^{1,2}$, Charlotte Mouden ${ }^{2}$, Joëlle Roume $^{3}$, Benmansour Abdelmajid ${ }^{4}$, Daniel Amram ${ }^{5}$, Clarisse Baumann ${ }^{6}$, Nicolas Chassaing ${ }^{7}$, Christine Coubes ${ }^{8}$, Laurence Faivre-Olivier ${ }^{9}$, Emmanuelle Ginglinger ${ }^{10}$, Marie Gonzales ${ }^{11}$, Annie Levy-Mozziconacci ${ }^{12}$, Sally-Ann Lynch $^{13}$, Sophie Naudion ${ }^{14}$, Laurent Pasquier ${ }^{15}$, Amélie Poidvin ${ }^{16}$, Fabienne Prieur ${ }^{17}$, Pierre Sarda ${ }^{8}$, Annick Toutain ${ }^{18}$, Valérie Dupé ${ }^{2}$, Linda Akloul $^{15}$, Sylvie Odent ${ }^{2,15}$, Marie de Tayrac ${ }^{1,2, *}$ and Véronique David ${ }^{1,2, *}$

${ }^{1}$ Service de Génétique Moléculaire et Génomique, CHU, Rennes, France

${ }^{2}$ UMR6290 Institut de Génétique et Développement de Rennes, Université de Rennes 1,

Rennes, France

${ }^{3}$ Service de Génétique Médicale, CHI, Poissy, France

${ }^{4}$ Cabinet de Pédiatrie, Oran, Algérie

${ }^{5}$ Unité de Génétique Clinique, CHI, Créteil, France

${ }^{6}$ Unité de Génétique Clinique, CHU Robert Debré, Paris, France

${ }^{7}$ Service de Génétique Médicale, CHU, Toulouse, France

${ }^{8}$ Département de Génétique Médicale, CHU, Montpellier, France

${ }^{9}$ Centre de Génétique, CHU, Dijon, France

${ }^{10}$ Service de Génétique, $\mathrm{CH}$, Mulhouse, France

${ }^{11}$ Service de Génétique et Embryologie Médicales, Hôpital Armand Trousseau, Paris, France

${ }^{12}$ Service de Gynécologie, CHU, Marseille, France

${ }^{13}$ Medical Genetics, Our Lady's Children Hospital, Dublin, Ireland

${ }^{14}$ Service de Génétique Médicale, CHU, Bordeaux, France

${ }^{15}$ Service de Génétique Clinique, CHU, Rennes, France

${ }^{16}$ Service d'Endocrinologie, CHU Robert Debré, Paris, France

${ }^{17}$ Service de Génétique Clinique, CHU, Saint-Etienne, France

${ }^{18}$ Service de Génétique, CHU, Tours, France

*In the authors opinion these individuals contributed equally to this work.

Running title: FGF, a new major pathway in HPE

Key words: Holoprosencephaly, FGF signaling pathway, multigenic inheritance, targeted NGS, brain malformation 


\begin{abstract}
Holoprosencephaly (HPE) is the most common congenital cerebral malformation in humans, characterized by impaired forebrain cleavage and midline facial anomalies. It presents a high heterogeneity, both in clinics and genetics. We have developed a novel targeted NGS assay and screened a cohort of 257 HPE patients. Mutations with high confidence in their deleterious effect were identified in approximately $24 \%$ of the cases and were held for diagnosis, while VUS were identified in $10 \%$ of cases. This study provides a new classification of genes that are involved in HPE. SHH, ZIC2 and SIX3 remain the top genes in term of frequency with GLI2, and are followed by FGF8 and FGFR1. The three minor HPE genes identified by our study are DLL1, DISPI and SUFU. Here we demonstrate that FGF signaling must now be considered as a major pathway involved in HPE. Interestingly, several cases of double mutations were found and argue for a polygenic inheritance of HPE. Altogether it supports that the implementation of next generation sequencing in HPE diagnosis is required to improve genetic counseling.
\end{abstract}

\title{
INTRODUCTION
}

Holoprosencephaly (HPE; MIM\# 236100) is the most frequent congenital brain malformation ( 1 in 10,000 live births, 1 in 250 conceptuses). It results from incomplete midline division of the prosencephalon between $18^{\text {th }}$ and $28^{\text {th }}$ day of gestation, affecting both the forebrain and the face (Dubourg et al., 2007; Marcorelles and Laquerriere, 2010). The clinical spectrum is very wide, ranging from severe HPE with a single cerebral ventricle and cyclopia to clinically unaffected carriers in familial HPE. Three classic anatomical classes have been described, in decreasing order of severity: alobar, semi-lobar, and lobar HPE. The full spectrum of HPE includes also middle interhemispheric variants (MIH) or syntelencephaly, septopreoptic HPE and microforms characterized by midline defects (eg, single maxillary median incisor 
(SMMI) or hypotelorism) without the brain malformations typical of HPE (Barkovich et al., 2002; Hahn et al., 2010; Lazaro et al., 2004; Simon et al., 2002).

Not only is HPE highly variable phenotypically, but also very heterogeneous etiologically (Bendavid et al., 2010; Pineda-Alvarez et al., 2010; Roessler and Muenke, 2010). HPE may be due to chromosome abnormalities, such as trisomy 13, 18, and triploidy, or may be one of the components of a multiple malformation syndrome, such as Smith-Lemli-Opitz or CHARGE syndrome. The Hartsfield syndrome associates HPE with ectrodactyly, with and without cleft lip and palate. HPE may also result from exposure to maternal diabetes during gestation (Johnson and Rasmussen, 2010; Miller et al., 2010). Isolated HPE presents a high genetic heterogeneity. To date heterozygous mutations in 15 genes have been identified in HPE patients with four major genes (Sonic hedgehog or SHH MIM\# 600725, ZIC2 MIM\#603073, SIX3 MIM\# 603714, TGIF1 MIM\# 602630), and eleven genes that are considered as minor genes (PTCH1 MIM\#601309, TDGF1 MIM\#187395, FOXH1 MIM\# 603621, GLI2 MIM\# 165230, DISP1 MIM\# 607502, FGF8 MIM\# 600483, GAS1 MIM\# 139185, CDON MIM\#608707, NODAL MIM\# 601265, DLL1 MIM\# 606582 and very recently STIL MIM\# 181590) (Arauz et al., 2010; Bae et al., 2011; Bendavid et al., 2010; Dupe et al., 2011; Mouden et al., 2015; Pineda-Alvarez et al., 2012). These genes encode proteins playing a role in early brain development, which mostly belong to the signaling pathway Shh, and to a lesser extent Nodal and Fgf pathways (Arauz et al., 2010; Mercier et al., 2013). Mutations in SHH, SIX3 and TGIF1 are inherited from an unaffected parent or parent harboring only a microform of HPE in $70 \%$ of the cases (Mercier et al., 2011). It suggests that other events are necessary to develop the disease. Consequently, the mode of inheritance initially described as autosomal dominant with an incomplete penetrance and a variable expression has been redefined (Odent et al., 1998; Mouden et al., 2016). HPE is now listed as a polygenic disease having multiple inheritance modes. Among them, polygenic 
inheritance would require two or more events involving genes from the same or different signaling pathways with functional relationship. This polygenic inheritance plays a role in the variability of the phenotype especially when there is a functional relationship between mutated genes, as this is the case for HPE genes (Mercier et al., 2013). This has significant implications for genetic counseling and for risk assessment of patient relatives.

Until recently, HPE molecular diagnosis had relied on the detection of point mutations in the four main HPE genes (SHH, ZIC2, SIX3 and TGIF1) by Sanger sequencing and on the search for deletions in either known HPE genes or in the entire genome (using CGH array).

Targeted next-generation sequencing (NGS) has been proven in the recent years to be very beneficial clinically, especially for the molecular diagnosis of genetically heterogeneous diseases, such as intellectual disability, hearing loss (Shearer et al., 2010), and ciliopathies like Bardet-Biedl syndrome (M'Hamdi et al., 2014). Targeted NGS appears to be more suitable for routine clinical practice than whole-exome sequencing as it provides better coverage of particular genes for a lower cost and easier and quicker data interpretation (Rehm, 2013). Therefore we have developed a targeted NGS panel for the molecular diagnosis of HPE by screening twenty genes positively involved in HPE or defined as candidates for this disorder using the Ion Torrent AmpliSeq and Ion Personal Genome Machine (PGM) strategy.

In a cohort of 271 HPE probands tested since the beginning of 2014, we were able to provide a diagnosis in approximately $24 \%$ of patients. We also show that components of the FGF signaling pathway are clearly involved in HPE.

\section{MATERIALS AND METHODS}

\section{Sample Collection}


A total of 257 patients (131 fetuses and 126 living children) with normal conventional karyotype were referred by the French geneticists from the eight different CLAD (Centres Labellisés pour les Anomalies du Développement) of the country, French centers of prenatal diagnosis (CPDPN), fetopathologists from the French Fetopathology Society (SOFFOET), as well as several European centers. The 257 patients are described in Table 1. This cohort includes 130 males and 127 females, who have been diagnosed with alobar $(n=62)$, semilobar $(n=54)$, lobar $(n=43)$, syntelencephaly $(n=12)$, HPE microform $(n=80)$, Hartsfield syndrome $(n=3)$ or Kallmann syndrome $(n=3)$. All samples were obtained with informed consent according to the protocols approved by the local ethics committee (Rennes hospital).

\section{Gene selection and panel design}

Gene selection was based on their proved or suspected involvement in HPE, or in syndromes including HPE, membership in signaling pathways implicated in HPE, and expression in the developing forebrain compatible with HPE. Known regulatory regions of SHH (LMBRI MIM\# 605522, RBM33) have also been included.

The panel was designed with Ion AmpliSeq ${ }^{\mathrm{TM}}$ Designer (Life Technologies, ThermoFisher Scientific). It includes coding and flanking intronic sequences (50 base pairs) of the following 20 genes: SHH (NM_000193.2), ZIC2 (NM_007129.3), SIX3 (NM_005413.3), TGIF1 (NM_170695.2), GLI2 (NM_005270.4), PTCH1 (NM_000264.3), GAS1 (NM_002048.2), TDGF1 (NM_003212.3), CDON (NM_016952.4), DISP1 (NM_032890.3), FOXH1 (NM_003923.2), NODAL (NM_018055.4), FGF8 (NM_033163.3), HHAT (NM_018194.4) MIM\# 605743, DLL1 (NM_005618.3), SUFU (NM_016169.3) MIM\# 607035, SOX2 (NM_003106.3) MIM\# 184429, RBM33 (NM_053043.2), LMBRI (NM_022458.3) and FGFR1 (NM_023110.2) MIM\# 136350. It covers 111 kb.

\section{Library preparation and DNA sequencing}


An adapter-ligated library was constructed with the Ion AmpliSeq Library Kit 2.0 (Life Technologies) following the manufacturer's protocol. Briefly, 10 ng of DNA was amplified in two pooled reactions then gathered together. Amplicons were partially digested at primer sequences before ligation with Ion Torrent adapters $\mathrm{P} 1$ and $\mathrm{A}$, and the adapter-ligated products were then purified with AMPure beads (Beckman Coulter Genomics, Brea, CA, USA), and PCR-amplified for 7 cycles. The resulting libraries of 11 patients were equalized using the Ion Library Equalizer Kit (Life Technologies) and then pooled.

Sample emulsion PCR, emulsion breaking, and enrichment were performed with the Ion PGM Template OT2 200 Kit (Life Technologies), according to the manufacturer's instructions. Briefly, an input concentration of one DNA template copy per Ion Sphere Particles (ISPs) was added to emulsion PCR master mix, and the emulsion was generated with an Ion OneTouch system (Life Technologies). Next, ISPs were recovered, and templatepositive ISPs were enriched with Dynabeads MyOne Streptavidin C1 beads (Life Technologies). The Qubit 2.0 fluorometer (Life Technologies) was used to confirm ISP enrichment. An Ion PGM 200 Sequencing Kit was used for sequencing reactions, as recommended in the protocol, and chips 316 were used to sequence barcoded samples on the Ion Torrent PGM for 500 dNTP-flows.

In order to achieve a complete coverage of at least the four main genes for each patient, six fragments, respectively one in $S H H$, four in ZIC2 and one in SIX3, were systematically studied by Sanger method. Depending on the coverage, analysis of other genes was completed according to the patient phenotype by Sanger sequencing.

\section{Bioinformatical analysis}

The sequencing data produced by the PGM were first processed with the Torrent Suite 4.2.1, Ion Torrent platform-specific pipeline including signal processing, adapter trimming, filtering 
of poor signal-profile reads and alignment to the hg19 human reference genome with TMAP (Torrent Mapping Alignment Program). Four independent variant calling algorithms from the Torrent suite were used.

The four VCF (variant calling format) files were combined and annotated with ANNOVAR (February 2014 build) (Wang et al., 2010). A gene-based annotation identified whether SNPs cause protein-coding changes and the amino acids that were affected based on RefSeq. A filter based annotation identified variants and their associated frequency that were reported in the following databases: dbSNP138, 1000-Genome (1000G), NHLBI-ESP, ExAC (Exome Aggregation Consortium) and ClinVar (Landrum et al., 2014). ANNOVAR was also used to annotate the predicted functional consequences of missense variants using dbNSFP (database $\begin{array}{lllll}\text { for } & \text { synonymous } & \text { SNP's } & \text { functional } & \text { predictions) }\end{array}$ (http://sites.google.com/site/jpopgen/dbNSFP) (Liu et al., 2011; Liu et al., 2013). This database compiles prediction scores and interpretation from ten different algorithms: SIFT, Polyphen2_HDIV, Polyphen2_HVAR, LRT, MutationTaster, MutationAssessor, FATHMM, CADD, MetaSVM and MetaLR (Suppl. Tables S1 and S2). Three conservation scores (GERP++, PhyloP and SiPhy) are also included in dbNSFP v2.6 (Suppl. Tables S1 and S2). The variant annotation was completed with "in-house" data regarding variants frequency within each run, across runs and during previous annotation helping to identify recurring false positives and polymorphisms. Furthermore only variants with a frequency less than $1 / 1,000$ in 1000G, EVS (Exome Variant Server), ExAC held our interest.

After variants validation by visualization with IGV (Integrative Genomics Viewer), complementary annotations were performed using Condel v2.0 (Gonzalez-Perez and LopezBigas, 2011) and Alamut Visual v2.4.5 (Interactive Biosoftware) to estimate variant pathogenicity. The information given by different tools were re-examined with caution to provide accurate results: PolyPhen (Adzhubei et al., 2013), SIFT (Kumar et al., 2009), 
Mutation Taster (Schwarz et al., 2014), and Align-GVGD (Tavtigian et al., 2006) were tested for exonic variants. In order to study the effect of potential splice variations, Alamut Visual integrates various splice site prediction methods: SpliceSiteFinder-like (Zhang, 1998), MaxEntScan (Yeo and Burge, 2004), NNSPLICE (Reese et al., 1997), GeneSplicer (Pertea et al., 2001), Human Splicing Finder (Desmet et al., 2009), ESEFinder (Cartegni et al., 2003), RESCUE-ESE (Fairbrother et al., 2002) and EX-SKIP (Raponi et al., 2011) were interrogated. The first five gave scores increasing with the importance of the predicted impact on the splice.

Finally, a variant was retained for diagnosis when a majority of tools predicted it as potentially deleterious and/or when family pedigree segregation was consistent. Nucleotide numbering uses +1 as the A of the ATG translation initiation codon in the reference sequence, with the initiation codon as codon 1. We use the tool ProteinPaint (http://pecan.stjude.org) for visualizing amino acid changes corresponding to the retained variants (Zhou et al., 2015).

\section{Mutation validation}

All variants with a potential deleterious effect were confirmed by Sanger sequencing. They were submitted to ClinVar (ClinVar accessions SCV000268717 - SCV000268738 on http://www.ncbi.nlm.nih.gov/clinvar/). Segregation analyses were performed whenever DNA was available for additional family members.

\section{RESULTS}

Targeted NGS analysis of the 257 patients identified candidate and diagnosis variants in $23.7 \%$ of the cases: mutations with high confidence in their deleterious effect in three of the main genes SHH, ZIC2 and SIX3 were identified in $13.2 \%$ of the cases $(34 / 257)$, and in other tested genes in $10.5 \%$ (27/257). For these cases, we were able to give a diagnosis. We also 
found variants classified as variants of uncertain significance (VUS) in 10\% (26/257) of the cases.

From these data, the ten first-ranked genes involved in HPE are SHH (5.8\%), ZIC2 (4.7\%), GLI2 (3.1\%), SIX3 (2.7\%), FGF8 (2.3\%), FGFR1 (2.3\%), DISP1 (1.2\%), DLL1 (1.2\%) and SUFU (0.4\%) (Table 1, Fig. 1). All variants were found in a heterozygous state and were held for diagnosis.

\section{SHH, ZIC2 and SIX3 retain their position of major genes.}

Description of the $S H H, Z I C 2$ and SIX3 mutations is provided in Figures 1 and 2. As previously described by Mercier et al. (Mercier et al., 2011), our results confirmed that SHH is the major gene implicated in HPE. SHH mutations are mostly missense (Fig. 1) and are inherited in $80 \%$ of cases of this study. The spectrum of clinical manifestations associated with $S H H$ mutations is very large and includes severe forms as well as microforms. ZIC2 is the second major gene, which is affected by all types of mutations: missense (42\%), frameshift and nonsense (42\%) and also splice mutations (16\%). ZIC2 alterations are generally associated with severe HPE forms and few facial features and are de novo in $92 \%$ of cases in our study. Probands with SIX3 mutation mostly had severe HPE correlated with severe facial features. Like $S H H$ mutations, SIX3 variants are mostly inherited.

Altogether, these results support that mutations in SHH and SIX3 are highly inherited, whereas most of the ZIC2 mutations are de novo.

\section{GLI2 is mostly involved in midline abnormalities.}

Six GLI2 heterozygous variants were hold for diagnosis (Fig. 1 and 3, Table 2, Suppl. Table S2).

The c.596dupG/p.Ala200Argfs*151 (A200Rfs*151) mutation was identified in a boy with nasal pyriform aperture atresia and was inherited from his asymptomatic mother. 
The c.790C>T/p.Arg264* (R264*) mutation was identified in a 2-years-old girl with isolated solitary median maxillary central incisor and was inherited from her asymptomatic mother.

The c.2064delC/p.Ser690Alafs*5 (S690Afs*5) mutation was identified in a 20-years-old girl with hexadactyly, choanal atresia, hypopituitarism and cerebellar atrophia. This mutation occurred de novo.

The c.2237G>A/p.Trp746* (W746*) mutation was identified in a male fetus aborted because of lobar holoprosencephaly, premaxillary agenesis, hexadactyly, pituitary hamartoma, and short femur. Moreover his karyotype revealed a mosaic fragility on chromosome 3 (3p24.1, so very far from $T D G F 1$ ). This mutation was not inherited from his mother, and DNA from the father was unavailable.

The c.4761G $>\mathrm{C} / \mathrm{p} . * 1587$ Tyrext*46 $(* 1587 \mathrm{Y})$ mutation was found in a 16-year-old boy with hypopituitarism, solitary median maxillary central incisor and choanal atresia. It was inherited from his asymptomatic mother.

The c.349G>A/p.Ala117Thr (A117T) variant was found in two brothers, one with hypopituitarism and optic atrophia, the other with bilateral cleft lip and palate. This variant was inherited from the father presenting only subtle hypotelorism. The effect of this variant is uncertain as it involves a moderately conserved amino acid and the physicochemical gap between alanine and threonine is low (Grantham distance $=58)$.

Except the A117T, which is of uncertain clinical significance, all the other variations modify the stop codon. They are inherited in the majority of cases, implicating that these variants in GLI2 clearly show incomplete penetrance.

Altogether, the mutations in GLI2 are mostly associated with spectrum linked to midline and characterized by solitary median maxillary central incisor and pituitary insufficiency. Only one is associated with classic HPE.

\section{$F G F 8$ reaches the top genes.}


Six patients of our cohort presented heterozygous variations in $F G F 8$ gene (Fig. 1 and 3, Table 2, Suppl. Table S2).

A fetus with semilobar HPE presented the c. 356C $>\mathrm{T} / \mathrm{p}$.Thr119Met $(\mathrm{T} 119 \mathrm{M})$ variant in $F G F 8$ in association with a splice mutation in FGFRl. The couple had already had a termination of pregnancy due to semilobar HPE and the paternal grandmother presents a right cleft lip. DNA samples were not available, preventing further Sanger validation.

The c.317C>A/p.Ala106Glu (A106E) was identified in 4-years old boy with semi-lobar HPE. This variant implicates a highly conserved aminoacid (through 13 species until Fugu) located in the interleukin-1/heparin-binding growth factor domain. It is predicted as possibly damaging by SIFT, PolyPhen and Mutation taster. This mutation occurred de novo. This is the first time that a $F G F 8$ mutation is described in association with syntelencephaly.

The c.385C >T/p.Arg129* (R129*) was identified twice in two unrelated families. The first patient is a boy with alobar HPE and the second one is a boy with syntelencephaly. In both cases, the mutation was inherited from the asymptomatic father.

The c.617G>A/p.Arg206Gln (R206Q) was also identified twice in two unrelated families. The first case is a 3 year-old girl with microform (pyriform aperture stenosis, solitary median maxillary central incisor, hypotelorism) presenting an additional variant in DLL1 (p.Asp601_Ile602delinsVal). These two variants are also present in her older sister who was operated on for bilateral cleft lip and palate and are inherited from the mother presenting hypotelorism and microretrognathism. So there is an apparent co-segregation of these mutations with minor signs of HPE spectrum in this family. The second case is a female fetus with lobar HPE.

Overall, the mutation frequency (2.2\%) in FGF8 demonstrates that this gene can be classified as a major gene.

FGFR1 is a new major gene in HPE. 
Six heterozygous variants in FGFRl (NM_023110.2) were identified in our cohort: five in the intracellular tyrosine kinase domain (TKD, aminoacids 478-767): p.Gly485Val, p.Gly490Arg, p.Gly643Asp, c.1977+1G>A, p.Glu692Lys, and one in the extracellular ligand binding domain (p.Arg250Pro) (Fig. 1 and 3, Table 2, Suppl. Table S2).

The c.1454G>T/p.Gly485Val (G485V) and the c.1468G>C/p.Gly490Arg (G490R) were identified in patients with Harstfield syndrome and occurred de novo. The latter has already been reported by Simonis et al. (Simonis et al., 2013).

The c.1928G>A/p.Gly643Asp (G643D) mutation occurred de novo in a patient with nasal pyriform aperture hypoplasia, single central incisor and intellectual deficiency. It involves a highly conserved residue (through 16 species from Caenorhabiditis elegans to Homo sapiens) located in the serine-threonine/tyrosine-protein kinase catalytic domain and the physicochemical gap between glycine and aspartate is important (Grantham distance $=94$ ). AlignGVGD, SIFT and MutationTaster predict a deleterious effect.

The c.1977+1G>A variant was identified in a patient with semilobar HPE in association with a variant in $F G F 8$, p.Thr119Met, as described above. The c.1977+1G $>$ A variant is predicted to induce a skipping of exon 17 by all five splice prediction tools.

The c.2074G>A/p.Glu692Lys (E692K) mutation was identified in a fetus with HPE and cleft lip and palate, and was inherited from his mother with hypogonadotropic hypogonadism.

The c.749G>C/p.Arg250Pro (R250P) mutation was identified in a boy with lobar HPE and bilateral cleft lip and palate. Sanger sequencing suggested a very low proportion of the mutated base (cytosine) to the normal base (guanine) in the father leucocyte DNA (Fig. 4). This was confirmed by NGS sequencing showing mosaicism for the presence of the mutation (GRCh37 genome build: g.38282214C $>\mathrm{G}$ ) with a frequency of $6 \%$ in the peripheral blood, and was perfectly correlated with the phenotype of the father presenting a microform with a right unilateral hypoplasia of the orbicularis of the upper lip and bilateral nasal slot, and MRI 
showed agenesis of the corpus callosum. The 15-month-old boy now presents diabetes insipidus and septo-optic dysplasia.

Mutations in FGFRl were recently described in Hartsfield syndrome (OMIM 300571), that is a rare and unique association of HPE and ectrodactyly, with or without cleft lip and palate, and variable additional features (Hong et al., 2016; Simonis et al., 2013). Here we identified four FGFRl mutations in patients presenting HPE without extremities abnormalities.

Minor HPE genes present mutations that are associated with a second one in most of the cases.

The three HPE minor genes identified by our study are DLL1, DISP1 and SUFU (Fig. 1, Table 2, Suppl. Table S2).

In the DLLl gene, we identified twice the same mutation c.1802_1804del/p.Asp601_Ile602delinsVal (or 601_602del) in two unrelated patients. First, this mutation was found in a patient with semilobar HPE and has already been reported by our group (Dupé et al., 2011). Secondly, it was identified in a 3 year-old girl with microform (pyriform aperture stenosis, solitary median maxillary central incisor, hypotelorism). It was found in association with a VUS in $F G F 8$ (R206Q); the two variants perfectly co-segregate with the phenotype in the family and may be implicated in the phenotype as we have shown that Fgf pathway might regulate expression of DLL1 in the chick developing brain (Dupé et al., 2011).

We also found the c.2117C>T/p.Ser706Leu (S706L) mutation in the DLL1 gene in a fetus with alobar HPE in association with an in-frame deletion in $S H H$ (c.1157_1180del/p.Leu386_Ala393del). The two mutations were however inherited from her asymptomatic father.

Regarding the DISPI gene, we identified two compound heterozygous mutations in a 9-yearold girl with a mild form of lobar HPE, facial dysmorphism and hypotelorism: the 
c.1087A $>\mathrm{G}$ transition leading to a missense mutation p.Asn363Asp (N363D) and the c.1657G>A transition leading to a missense mutation p.Glu553Lys (E553K). The p.Asn363Asp mutation was inherited from the father and the p.Glu553Lys mutation was inherited from the mother (Mouden et al., 2016).

In one polymalformative fetus with bilateral cleft lip and facial dysmorphism suggesting HPE microform, we found a nonsense heterozygous mutation c.2898G>A or p.Trp966* (W966*) in DISP1, associated with a mutation in SUFU (c.1022C > T/p.Pro341Leu) that substitutes the last base of exon 8 and that is predicted deleterious by most bioinformatics prediction tools mutation. Family study unfortunately could not be performed because DNA samples were not available.

These results suggest that mutations in minor genes would be found more often in HPE patients with polygenic inheritance.

\section{DISCUSSION}

HPE is a very complex disorder both in clinical and genetic terms involving two or more genetic events. We present here the first large HPE series studied by targeted NGS and we provide a new classification of genes involved in HPE. SHH, ZIC2 and SIX3 remain the top genes in terms of importance with GLI2, and are followed by FGF8 and FGFRI. The fraction of mutations in the major genes $(S H H, Z I C 2, S I X 3)$ is reduced in the present study compared to previous studies (Mercier et al., 2011); it is probably due to the present cohort which included more patients with microforms and syntelencephaly. TGIF1 was previously classified as a major HPE gene (Mercier et al., 2011) but did not present any mutation in our study. Similarly PTCH1, GAS1, TDGF1, CDON, FOXH1, NODAL and SHH regulating sequences $L M B R 1$ and RBM33 showed no mutations held for diagnosis in the 257 cases sequenced. New case-control studies need to be performed in larger cohorts to better evaluate their role and diagnosis potential in HPE. Such studies may be much more capable to 
evaluate the implication of rare variants. The candidate HHAT and SOX2 genes did not present any mutation either.

Significantly, the identification of numerous mutations in FGF8 and FGFRI in our cohort strengthens FGF signaling involvement in HPE.

FGF8 is a ligand of the large fibroblast growth factor (FGF) family and is important for gonadotropin releasing hormone $(\mathrm{GnRH})$ neuronal development with human mutations resulting in hypogonadotropic hypogonadism and Kallmann syndrome (Falardeau et al., 2008; Hardelin and Dode, 2008). Our targeted NGS approach demonstrates that mutation in FGF8 occurs more commonly than previously thought (Arauz et al., 2010; McCabe et al., 2011). The phenotype associated with $F G F 8$ alterations is variable and mutation can be de novo or inherited. Interestingly, the same inherited nonsense mutation (p.Arg129*) was identified in two unrelated patients, one with a severe HPE and the other with a mild form. It supports that another event could be necessary to lead to severe HPE.

We also describe here convincing examples of FGFR1 mutations in patients with isolated HPE. FGFR1 belongs to the tyrosine kinase receptor superfamily and contains an extracellular ligand binding domain with three immunoglobulin (Ig)-like domains (D1-D3) and a cytoplasmic domain responsible for tyrosine kinase activity (Fig. 3). The clinical manifestations of $F G F R 1$ alterations are very heterogeneous since loss-of-function mutations in FGFRl have been linked to Kallman syndrome (Dode et al., 2003; Albuisson et al., 2005; Villanueva and de Roux, 2010), hypogonadotropic hypogonadism with or without anosmia (Costa-Barbosa et al., 2013; Villanueva et al., 2015; Vizeneux et al., 2013), and Hartsfield syndrome (Hong et al., 2016; Simonis et al., 2013). Gain-of-function mutations in FGFR1 have also been identified in about 5\% of Pfeiffer syndrome with or without craniosynostosis (Chokdeemboon et al., 2013). We describe here one case of FGFRl mutation (p.Glu692Lys) associated both with Kallmann syndrome and HPE. The location of this mutation is 
consistent with Kallmann syndrome as mutations of neighboring residues (p.Leu590Pro, p.Ile693Phe) were already described in patients with this syndrome (Bailleul-Forestier et al., 2010; Dodé et al., 2007).

Out of the six FGFR1 mutations described in our study, two were found in patients with Hartsfield syndrome. Previous reports of Hartsfield syndrome implicate FGFRI mutations in the ATP binding site and the protein tyrosine kinase domain (Dhamija et al., 2014; Hong et al., 2016; Simonis et al., 2013). These mutations would have a dominant-negative activity that would account for the most severe phenotype of Hartsfield syndrome (Hong et al., 2016). Concordantly, the two FGFRl mutations (p.Gly485Val, p.Gly490Arg) that are associated with Hartsfield syndrome in our cohort are localized in the region coding for ATP binding site (Fig. 3). However, two of the mutations identified in HPE patients without abnormalities of the extremities are also found in the region coding for activation loop of the protein tyrosine kinase domain (p.Gly643Asp; c.1977+1G>A). We hypothesized that these FGFR1 mutations rather lead to a classic loss of function (Hong et al., 2016). FGF8 and FGFR1 are not the only members of the FGF family to be expressed in the early forebrain. Other members should be considered as strong potential candidates for HPE.

FGF signaling pathway plays a dominant role in embryonic development and is essential for ventral telencephalon development and digits formation (Ellis et al., 2015; Gutin et al., 2006; Li et al., 2005). FGF signaling is involved in maintaining Shh expression in the prechordal tissue, where it plays a crucial role in induction of the ventral forebrain (Ellis et al., 2015). FGFR1 also maintains expression of Shh in the developing limb (Li et al., 2005). According to our hypothesis, dominant-negative FGFR1 mutations would lead to a more severe downregulation of Shh activity compared to a classic loss of function. It would explain the presence of limb defect in Hartsfield syndrome similar to those observed in the Shh-/knockout mice (Chiang et al., 1996). 
The knowledge of the mode of inheritance in HPE has evolved since the description of an autosomal dominant model with an incomplete penetrance and a variable expression (Odent et al., 1998) through an autosomal dominant model with modifier genes (Roessler et al., 2012). Thanks to our NGS strategy targeting twenty genes, we have shown that sixteen per cent of mutations kept for diagnosis was found in association with a second one (FGF8/FGFR1, FGF8/DLL1, DLL1/SHH, DISP1/DISP1, DISP1/SUFU). These cases of double-mutations in two different genes - and even in the same one - strengthen the polygenic inheritance previously illustrated by Mouden et al. (Mouden et al., 2016). Here, a second event in $F G F 8$ was identified in one patient with FGFRI mutation. In the same way, a gene synergistic interaction between a deleterious FGFRl allele transmitted from one parent and a loss-of-function allele in $F G F 8$ from the other parent was recently described in two sisters with semilobar and lobar HPE respectively (Hong et al., 2016). Altogether these observations strongly suggest that a cumulative effect on the FGF signaling pathway leads to HPE. We showed that most of mutations were inherited mainly from an asymptomatic parent, which suggests that another event could be necessary to cause HPE. The important and wide variability of expression from an asymptomatic to severe form for a same mutation, the incomplete penetrance and the identification of several mutations in the same patient argue for this oligogenic inheritance. Furthermore, the description of numerous mouse models carrying mutations in two genes of the same or different signaling pathways involved in forebrain development strongly support this mode of inheritance by showing that a cumulative partial inhibition of signaling pathways is necessary to develop HPE (Allen et al., 2007; Krauss, 2007; Mercier et al., 2013). However, only a few examples of digenic inheritance in human were reported in the literature until now (Hong et al., 2016; Lacbawan et al., 2009; Ming and Muenke, 2002; Mouden et al., 2016; Nanni et al., 1999). The present study demonstrates that digenism would not be so rare in human HPE. Systematic 
implementation of next generation sequencing in HPE diagnosis will be necessary to account for this multigenic inheritance and to improve genetic counselling.

\section{ACKNOWLEDGMENTS}

This work was supported by the CHU of Rennes (Innovation Project).

We would like to thank the families for their participation in the study, all clinicians who referred HPE cases, the eight CLAD (Centres Labellisés pour les Anomalies du Développement) within France that belong to FECLAD, French centers of prenatal diagnosis (CPDPN) and the SOFFOET for fetus cases, and the "filière AnDDI-Rares".

We particularly thank all members of the Molecular Genetics Laboratory (CHU, Rennes) and of the Department of Genetics and Development (UMR6290 CNRS, Université Rennes 1) for their help and advice. We are grateful to Артем Ким for carefully reading this manuscript.

The authors acknowledge the Centre de Ressources Biologiques (CRB) Santé BB-003300056 (http://www.crbsante-rennes.com) of Rennes for managing patient samples.

\section{REFERENCES}

Adzhubei IA, Schmidt S, Peshkin L, Ramensky VE, Gerasimova A, Bork P, Kondrashov AS, SunyaeV SR. 2010. A method and server for predicting damaging missense mutations. Nat Methods 7(4):248-49.

Adzhubei I, Jordan DM, Sunyaev SR. 2013. Predicting Dunctional Effect of Human Missense Mutations Using PolyPhen-2. Curr Protoc Hum Genet 7.

Albuisson J, Pêcheux C, Carel JC, Lacombe D, Leheup B, Lapuzina P, Bouchard P, Legius E, Matthijs G, Wasniewska M, Delpech M, Joung J et al. 2005. Kallmann syndrome: 14 novel mutations in KAL1 and FGFR1 (KAL2). Hum Mutat 25(1):98-99.

Allen BL, Tenzen T, McMahon AP. 2007. The Hedgehog-binding proteins Gas1 and Cdo cooperate to positively regulate Shh signaling during mouse development. Genes Dev 21:1244-1257. 
Arauz RF, Solomon BD, Pineda-Alvarez DE, Gropman aL, Parsons Ja, Roessler E, Muenke M. 2010. A hypomorphic allele in the FGF8 gene contributes to holoprosencephaly and is allelic to gonadotropin-releasing hormone deficiency in humans. Mol Syndromol 1:59-66.

Bae GU, Domené S, Roessler E, Schachter K, Kang JS, Muenke M, Krauss RS. 2011. Mutations in CDON, encoding a hedgehog receptor, result in holoprosencephaly and defective interactions with other hedgehog receptors. Am J Hum Genet 89:231-240.

Bailleul-Forestier I, Gros C, Zenaty D, Bennaceur S, Leger J, de Roux N. 2010. Dental agenesis in Kallmann syndrome individuals with FGFR1 mutations. Int J Paediatr Dent 20(4):305-12.

Barkovich AJ, Simon EM, Clegg NJ, Kinsman SL, Hahn JS. 2002. Analysis of the cerebral cortex in holoprosencephaly with attention to the sylvian fissures. AJNR Am J Neuroradiol 23(1):14350.

Bendavid C, Dupe V, Rochard L, Gicquel I, Dubourg C, David V. 2010. Holoprosencephaly: An update on cytogenetic abnormalities. Am J Med Genet C Semin Med Genet 154C(1):86-92.

Cartegni L, Wang J, Zhu Z, Zhang MQ, Krainer AR. 2003. ESEfinder: A web resource to identify exonic splicing enhancers. Nucleic Acids Res 31(13):3568-71.

Chiang C, Litingtung Y, Lee E, Young KE, Corden JL, Westphal H, Beachy Pa. 1996. Cyclopia and defective axial patterning in mice lacking Sonic hedgehog gene function. Nature. p 407-413.

Chokdeemboon C, Mahatumarat C, Rojvachiranonda N, Tongkobpetch S, Suphapeetiporn K, Shotelersuk V. 2013. FGFR1 and FGFR2 mutations in Pfeiffer syndrome. J Craniofac Surg 24(1):150-2.

Chun S, Fay JC. 2009. Identification of deleterious mutations within three human genomes. Genome Res 19(9):1553-61.

Costa-Barbosa FA, Balasubramanian R, Keefe KW, Shaw ND, Al-Tassan N, Plummer L, Dwyer AA, Buck CL, Choi JH, Seminara SB, Quinton R, Monies D et al. 2013. Prioritizing genetic testing in patients with Kallmann syndrome using clinical phenotypes. J Clin Endocrinol Metab 98(5):E943-53. 
Davydov EV, Goode DL, Sirota M, Cooper GM, Sodow A, Batzoglou S. 2010. Identifying a high fraction of the human genome to be under selective constraint using GERP++. PLoS Comput Biol 6(12):e1001025.

Desmet FO, Hamroun D, Lalande M, Collod-Beroud G, Claustres M, Beroud C. 2009. Human Splicing Finder: an online bioinformatics tool to predict splicing signals. Nucleic Acids Res 37(9):e67.

Dhamija R, Kirmani S, Wang X, Ferber MJ, Wieben ED, Lazaridis KN, Babovic-Vuksanovic D. 2014. Novel de novo heterozygous FGFR1 mutation in two siblings with Hartsfield syndrome: a case of gonadal mosaicism. Am J Med Genet A 164A(9):2356-9.

Dodé C, Levilliers J, Dupont JM, De Paepe A, Le Du N, Soussi-Yanicostas N, Coimbra RS, Delmaghani S, Compain-Nouaille S, Baverel F, Pecheux C, Le Tessier D et al. 2003. Loss-offunction mutations in FGFR1 cause autosomal dominant Kallmann syndrome. Nat Genet 33(4):463-5.

Dodé C, Fouveaut C, Mortier G, Janssens S, Bertherat J, Mahoudeau J, Kottler ML, Chabrolle C, Gancel A, François I, Devriendt K, Wolczynski S et al. 2006. Novel FGFR1 sequence variants in Kallmann syndrome, and genetic evidence that the FGFR1c isoform is required in olfactory bulb and palate morphogenesis. Hum Mut 28(1):97-98.

Dong C, Wei P, Jian X, Gibbs R, Boerwinkle E, Wang K, Liu X. 2015. Comparison and integration of deleteriousness prediction methods for nonsynonymous SNVs in whole exome sequencing studies. Hum Mol genet 24(8):2125-37.

Dubourg C, Bendavid C, Pasquier L, Henry C, Odent S, David V. 2007. Holoprosencephaly. Orphanet J Rare Dis 2:8.

Dupe V, Rochard L, Mercier S, Le Petillon Y, Gicquel I, Bendavid C, Bourrouillou G, Kini U, Thauvin-Robinet C, Bohan TP, Odent S, Dubourg C et al. 2011. NOTCH, a new signaling pathway implicated in holoprosencephaly. Hum Mol Genet 20(6):1122-31. 
Dupé V, Rochard L, Mercier S, Le Pétillon Y, Gicquel I, Bendavid C, Bourrouillou G, Kini U, Thauvin-Robinet C, Bohan TP, Odent S, Dubourg C et al. 2011. NOTCH, a new signaling pathway implicated in holoprosencephaly. Hum Mol Genet 20:1122-1131.

Ellis PS, Burbridge S, Soubes S, Ohyama K, Ben-Haim N, Chen C, Dale K, Shen MM, Constam D, Placzek M. 2015. ProNodal acts via FGFR3 to govern duration of Shh expression in the prechordal mesoderm. Development 142(22):3821-32.

Fairbrother WG, Yeh RF, Sharp PA, Burge CB. 2002. Predictive identification of exonic splicing enhancers in human genes. Science 297(5583):1007-13.

Falardeau J, Chung WC, Beenken A, Raivio T, Plummer L, Sidis Y, Jacobson-Dickman EE, Eliseenkova AV, Ma J, Dwyer A, Quinton R, Na S et al. 2008. Decreased FGF8 signaling causes deficiency of gonadotropin-releasing hormone in humans and mice. J Clin Invest $118(8): 2822-31$.

Garber M, Guttman M, Clamp M, Zody MC, Friedman N, Xie X. 2009. Identifying novel constrained elements by exploiting biased substitution patterns. Bioinformatics 25(12):i54-62.

Gonzalez-Perez A, Lopez-Bigas N. 2011. Improving the assessment of the outcome of nonsynonymous SNVs with a consensus deleteriousness score, Condel. Am J Hum Genet 88(4):440-9.

Gutin G, Fernandes M, Palazzolo L, Paek H, Yu K, Ornitz DM, McConnell SK, Hebert JM. 2006. FGF signalling generates ventral telencephalic cells independently of SHH. Development 133(15):2937-46.

Hahn JS, Barnes PD, Clegg NJ, Stashinko EE. 2010. Septopreoptic holoprosencephaly: a mild subtype associated with midline craniofacial anomalies. AJNR Am J Neuroradiol 31(9):1596601.

Hardelin JP, Dode C. 2008. The complex genetics of Kallmann syndrome: KAL1, FGFR1, FGF8, PROKR2, PROK2, et al. Sex Dev 2(4-5):181-93. 
Hong S, Hu P, Marino J, Hufnagel SB, Hopkin RJ, Toromanovic A, Richieri-Costa A, Ribeiro-Bicudo LA, Kruszka P, Roessler E, Muenke M. 2016. Dominant-negative kinase domain mutations in FGFR1 can explain the clinical severity of Hartsfield syndrome. Hum Mol Genet.

Johnson CY, Rasmussen SA. 2010. Non-genetic risk factors for holoprosencephaly. Am J Med Genet C Semin Med Genet 154C(1):73-85.

Kircher M, Witten DM, Jain P, O’Roak BJ, Cooper GM, Shendure J. 2014. A general framework for estimating the relative pathogenicity of human genetic variants. Nat Genet 46(3):310-15.

Krauss RS. 2007. Holoprosencephaly: new models, new insights. Expert Rev Mol Med 9:1-17.

Kumar P, Henikoff S, Ng PC. 2009. Predicting the effects of coding non-synonymous variants on protein function using the SIFT algorithm. Nat Protoc 4(7):1073-81.

Lacbawan F, Solomon BD, Roessler E, El-Jaick K, Domene S, Velez JI, Zhou N, Hadley D, Balog JZ, Long R, Fryer a, Smith W et al. 2009. Clinical spectrum of SIX3-associated mutations in holoprosencephaly: correlation between genotype, phenotype and function. J Med Genet 46:389-398.

Landrum MJ, Lee JM, Riley GR, Jang W, Rubinstein WS, Church DM, Maglott DR. 2014. ClinVar: public archive of relationships among sequence variation and human phenotype. Nucleic Acids Res 42(Database issue):D980-5.

Lazaro L, Dubourg C, Pasquier L, Le Duff F, Blayau M, Durou MR, de la Pintiere AT, Aguilella C, David V, Odent S. 2004. Phenotypic and molecular variability of the holoprosencephalic spectrum. Am J Med Genet A 129A(1):21-4.

Li C, Xu X, Nelson DK, Williams T, Kuehn MR, Deng CX. 2005. FGFR1 function at the earliest stages of mouse limb development plays an indispensable role in subsequent autopod morphogenesis. Development 132(21):4755-64.

Liu X, Jian X, Boerwinkle E. 2011. dbNSFP: a lightweight database of human nonsynonymous SNPs and their functional predictions. Hum Mutat 32(8):894-9.

Liu X, Jian X, Boerwinkle E. 2013. dbSNP v2.0: a database of human non-synonymous SNVs and their functional predictions and annotations. Hum Mutat 34(9):E2393-402. 
M'Hamdi O, Redin C, Stoetzel C, Ouertani I, Chaabouni M, Maazoul F, M'Rad R, Mandel JL, Dollfus H, Muller J, Chaabouni H. 2014. Clinical and genetic characterization of Bardet-Biedl syndrome in Tunisia: defining a strategy for molecular diagnosis. Clin Genet 85(2):172-7.

Marcorelles P, Laquerriere A. 2010. Neuropathology of holoprosencephaly. Am J Med Genet C Semin Med Genet 154C(1):109-19.

McCabe MJ, Gaston-Massuet C, Tziaferi V, Gregory LC, Alatzoglou KS, Signore M, Puelles E, Gerrelli D, Farooqi IS, Raza J, Walker J, Kavanaugh SI et al. 2011. Novel FGF8 mutations associated with recessive holoprosencephaly, craniofacial defects, and hypothalamo-pituitary dysfunction. J Clin Endocrinol Metab 96(10):E1709-18.

Mercier S, David V, Ratié L, Gicquel I, Odent S, Dupé V. 2013. NODAL and SHH dose-dependent double inhibition promotes an HPE-like phenotype in chick embryos. Dis Model Mech 6:53743.

Mercier S, Dubourg C, Garcelon N, Campillo-Gimenez B, Gicquel I, Belleguic M, Ratie L, Pasquier L, Loget P, Bendavid C, Jaillard S, Rochard L et al. 2011. New findings for phenotypegenotype correlations in a large European series of holoprosencephaly cases. J Med Genet 48:752-760.

Miller EA, Rasmussen SA, Siega-Riz AM, Frias JL, Honein MA. 2010. Risk factors for nonsyndromic holoprosencephaly in the National Birth Defects Prevention Study. Am J Med Genet C Semin Med Genet 154C(1):62-72.

Ming JE, Muenke M. 2002. Multiple hits during early embryonic development: digenic diseases and holoprosencephaly. Am J Hum Genet 71:1017-1032.

Mouden C, de Tayrac M, Dubourg C, Rose S, Carré W, Hamdi-Rozé H, Babron M-C, Akloul L, Héron-Longe B, Odent S, Dupé V, Giet R et al. 2015. Homozygous STIL Mutation Causes Holoprosencephaly and Microcephaly in Two Siblings. Plos One 10:e0117418.

Mouden C, Dubourg C, Carre W, Rose S, Quelin C, Akloul L, Viot G, Salhi H, Darnault P, Odent S, Dupe V, David V. 2016. Complex mode of inheritance in holoprosencephaly revealed by whole exome sequencing. Clin Genet. 
Nanni L, Ming JE, Bocian M, Steinhaus K, Bianchi DW, de Die-Smulders C, Giannotti A, Imaizumi K, Jones KL, Del Campo M, Martin RA, Meinecke P et al. 1999. The mutational spectrum of the Sonic Hedgehog gene in holoprosencephaly: SHH mutations cause a significant proportion of autosomal dominant holoprosencephaly. Hum Mol Genet 8:2479-2488.

Odent S, Le Marec B, Munnich A, Le Merrer M, Bonaiti-Pellie C. 1998. Segregation analysis in nonsyndromic holoprosencephaly. Am J Med Genet 77(2):139-43.

Pertea M, Lin X, Salzberg SL. 2001. GeneSplicer: a new computational method for splice site prediction. Nucleic Acids Res 29(5):1185-90.

Pineda-Alvarez DE, Dubourg C, David V, Roessler E, Muenke M. 2010. Current recommendations for the molecular evaluation of newly diagnosed holoprosencephaly patients. Am J Med Genet C Semin Med Genet 154C(1):93-101.

Pineda-Alvarez DE, Roessler E, Hu P, Srivastava K, Solomon BD, Siple CE, Fan CM, Muenke M. 2012. Missense substitutions in the GAS1 protein present in holoprosencephaly patients reduce the affinity for its ligand, SHH. Hum Genet 131(2):301-10.

Raponi M, Kralovicova J, Copson E, Divina P, Eccles D, Johnson P, Baralle D, Vorechovsky I. 2011. Prediction of single-nucleotide substitutions that result in exon skipping: identification of a splicing silencer in BRCA1 exon 6. Hum Mutat 32(4):436-44.

Reese MG, Eeckman FH, Kulp D, Haussler D. 1997. Improved splice site detection in Genie. J Comput Biol 4(3):311-23.

Rehm HL. 2013. Disease-targeted sequencing: a cornerstone in the clinic. Nat Rev Genet 14(4):295300.

Reva B, Antipin Y, Sander C. 2011. Predicting the functional impact of protein mutations: application to cancer genomics. 39(17):e118.

Roessler E, Muenke M. 2010. The molecular genetics of holoprosencephaly. Am J Med Genet C Semin Med Genet 154C(1):52-61. 
Roessler E, Velez JI, Zhou N, Muenke M. 2012. Utilizing prospective sequence analysis of SHH, ZIC2, SIX3 and TGIF in holoprosencephaly probands to describe the parameters limiting the observed frequency of mutant genexgene interactions. Mol Genet Metab 105(4):658-64.

Schwarz JM, Rödelsperger C, Schuelke M, Seelow D. 2010. MutationTaster evaluates diseasecausing potential of sequence alterations. Nat Methods 7(8):575-76.

Schwarz JM, Cooper DN, Schuelke M, Seelow D. 2014. MutationTaster2: mutation prediction for the deep-sequencing age. Nat Methods 11(4):361-2.

Shearer AE, DeLuca AP, Hildebrand MS, Taylor KR, Gurrola J, 2nd, Scherer S, Scheetz TE, Smith RJ. 2010. Comprehensive genetic testing for hereditary hearing loss using massively parallel sequencing. Proc Natl Acad Sci U S A 107(49):21104-9.

Shihab HA, Gough J, Cooper DN, Stenson PD, Barker GL, Edwards KJ, Day IN, Gaunt TR. 2013. Predicting the functional, molecular, and phenotypic consequences of amino acids substitutions using hidden Markov models. Hum Mutat 34(1):57-65.

Siepel A, Pollard KS, Haussler D. 2006. New methods for detecting lineage-specific selection. Proceedings of the $10^{\text {th }}$ international conference on research in computational molecular biology (RECOMB 2006):190-205.

Simon EM, Hevner RF, Pinter JD, Clegg NJ, Delgado M, Kinsman SL, Hahn JS, Barkovich AJ. 2002. The middle interhemispheric variant of holoprosencephaly. AJNR Am J Neuroradiol 23(1):151-6.

Simonis N, Migeotte I, Lambert N, Perazzolo C, de Silva DC, Dimitrov B, Heinrichs C, Janssens S, Kerr B, Mortier G, Van Vliet G, Lepage P et al. 2013. FGFR1 mutations cause Hartsfield syndrome, the unique association of holoprosencephaly and ectrodactyly. J Med Genet 50(9):585-92.

Tavtigian SV, Deffenbaugh AM, Yin L, Judkins T, Scholl T, Samollow PB, de Silva D, Zharkikh A, Thomas A. 2006. Comprehensive statistical study of 452 BRCA1 missense substitutions with classification of eight recurrent substitutions as neutral. J Med Genet 43(4):295-305.

Villanueva C, de Roux N. 2010. FGFR1 mutations in Kallmann syndrome. Front Horm Res 39:51-61. 
Villanueva C, Jacobson-Dickman E, Xu C, Manouvrier S, Dwyer AA, Sykiotis GP, Beenken A, Liu Y, Tommiska J, Hu Y, Tiosano D, Gerard M et al. 2015. Congenital hypogonadotropic hypogonadism with split hand/foot malformation: a clinical entity with a high frequency of FGFR1 mutations. Genet Med 17(8):651-9.

Vizeneux A, Hilfiger A, Bouligand J, Pouillot M, Brailly-Tabard S, Bashamboo A, McElreavey K, Brauner R. 2013. Congenital hypogonadotropic hypogonadism during childhood: presentation and genetic analyses in 46 boys. Plos One 8(10):e77827.

Wang K, Li M, Hakonarson H. 2010. ANNOVAR: functional annotation of genetic variants from high-throughput sequencing data. Nucleic Acids Res 38(16):e164.

Yeo G, Burge CB. 2004. Maximum entropy modeling of short sequence motifs with applications to RNA splicing signals. J Comput Biol 11(2-3):377-94.

Zhang MQ. 1998. Statistical features of human exons and their flanking regions. Hum Mol Genet 7(5):919-32.

Zhou X, Edmonson MN, Wilkinson MR, Patel A, Wu G, Liu Y, Li Y, Zhang Z, Rusch MC, Parker M, Becksfort J, Downing JR et al. 2015. Exploring genomic alteration in pediatric cancer using ProteinPaint. Nat Genet 48(1):4-6. 


\section{FIGURE LEGENDS}

Figure 1. Distribution of mutations held for diagnosis in the top ten holoprosencephaly genes tested by targeted NGS.

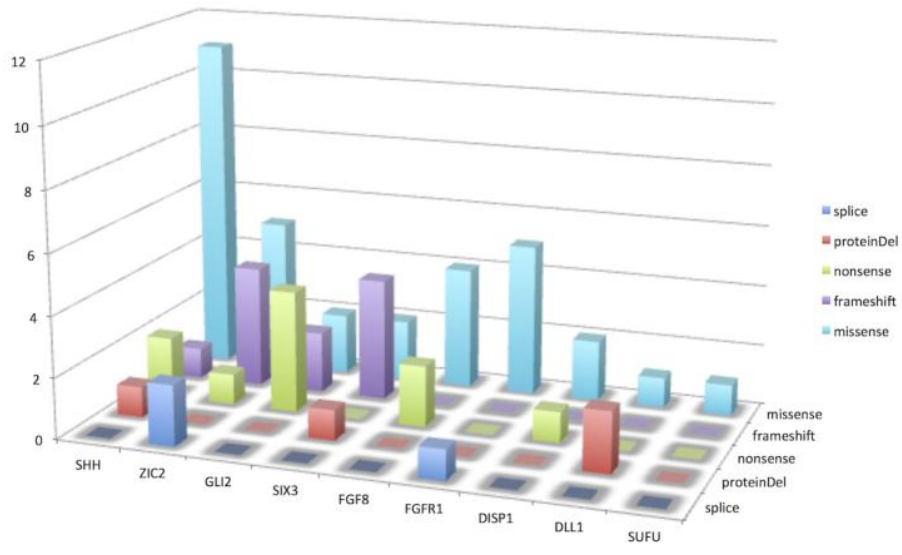

Figure 2. Mutational landscape of SHH, ZIC2 and SIX3 genes. This comprehensive visualization of sequence mutations was performed with ProteinPaint (http://pecan.stjude.org). Mutations are presented as filled circles with colors corresponding to mutation type: blue for missense, orange for nonsense, brown for deletion, red for frameshift and purple for splice mutations. The GenBank references used were NM_000193.2 for SHH, NM_007129.3 for ZIC2 and NM_005413.3 for SIX3.

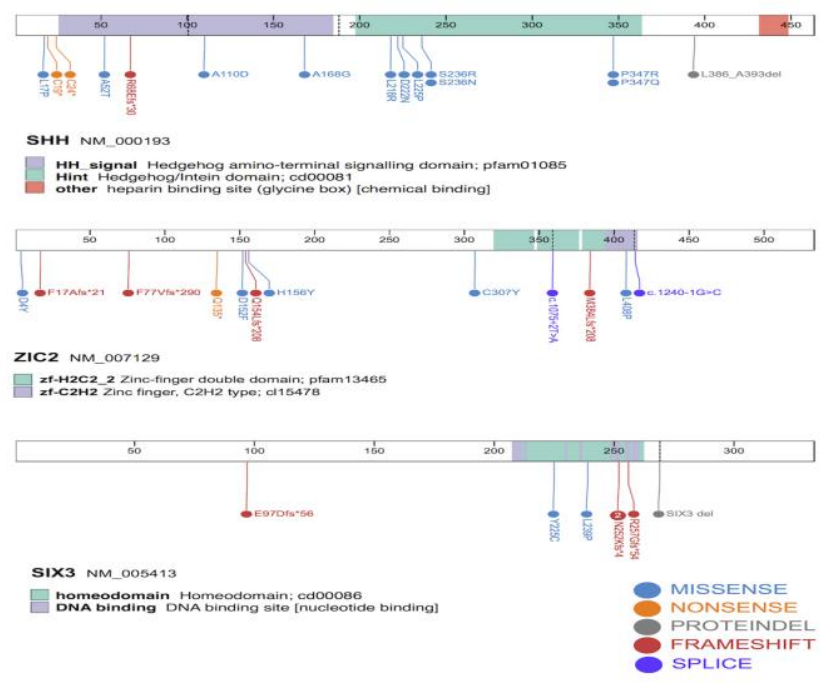


Figure 3. Mutational landscape of $F G F 8, F G F R 1$ and $G L I 2$ genes, performed with ProteinPaint. The GenBank references used were NM_033163.3 for FGF8, NM_023110.2 for FGFR1 and NM_005413.3 for GLI2.

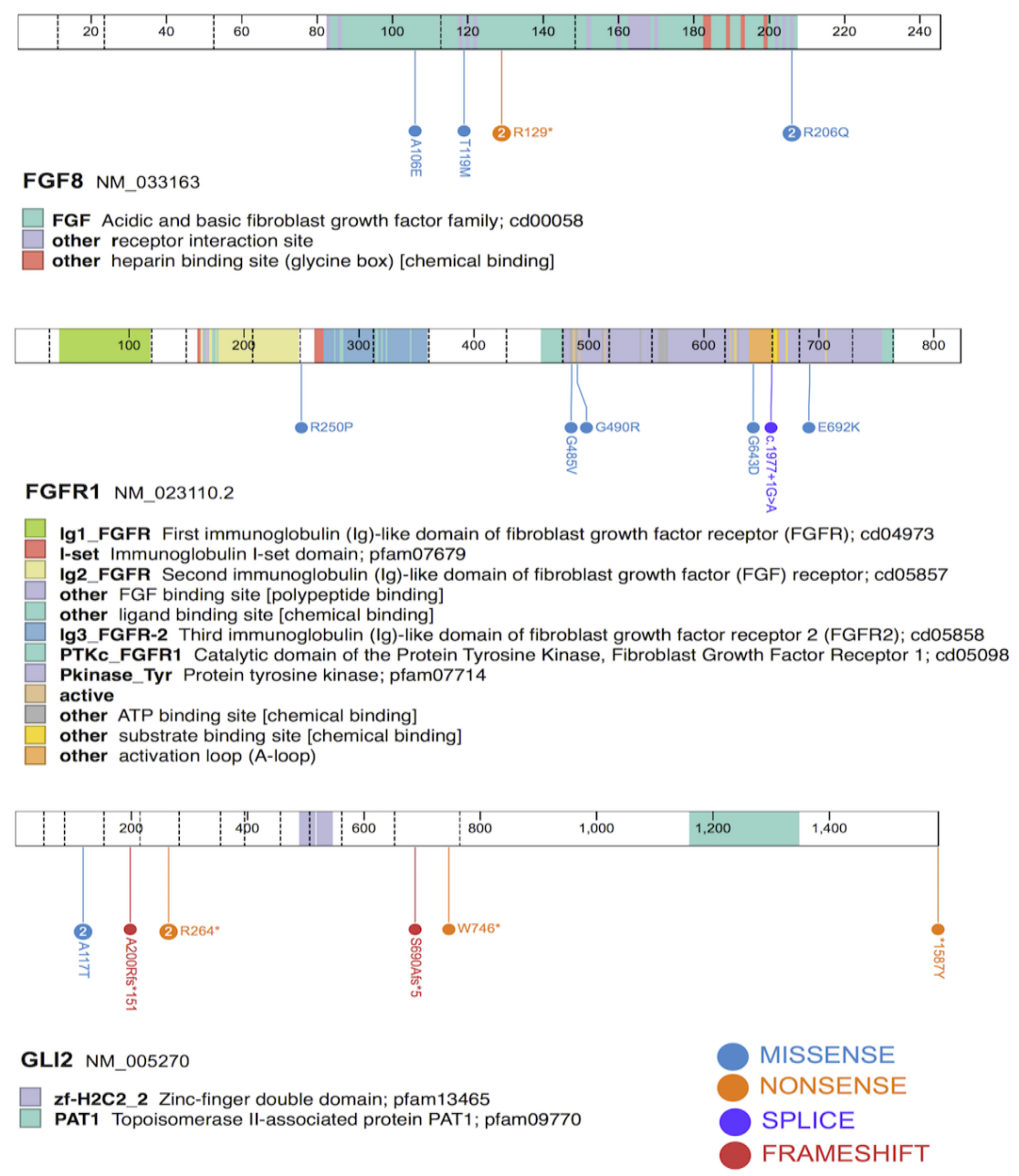

Figure 4. p.Arg250Pro (R250P) mutation in FGFR1. (I) Proband. (II) Father. (a) Partial FGFR1 electrephoregrams (upper: forward strand; lower: reverse strand) and c.749G>C (NM_023110.2) mutation identified in proband in a heterozygous state, and in father in trace on the reverse strand. (b) Visualisation of the g.38282214C $>\mathrm{G}$ (GRCh37 genome build) variation in IGV obtained by targeted NGS. (c) Facial photograph of the proband with bilateral cleft lip palate; lateral photograph of the father with right unilateral hypoplasia of the orbicularis of the upper lip and bilateral nasal slot. (d) Prenatal MRI showing lobar HPE in the proband, and MRI showing agenesis of the corpus callosum in the father. 


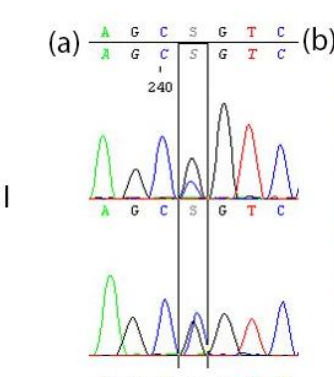

(a) \begin{tabular}{lll|llll}
$A$ & $G$ & $C$ & $G$ & $G$ & $T$ & $C$ \\
\hline$A$ & $G$ & $C$ & $G$ & $G$ & $T$ & $C$ \\
\hline & &
\end{tabular}

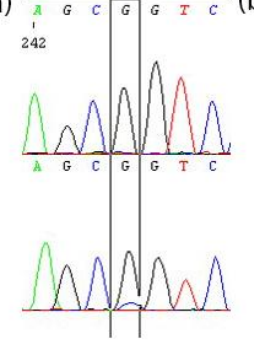

C.749G $>$ C
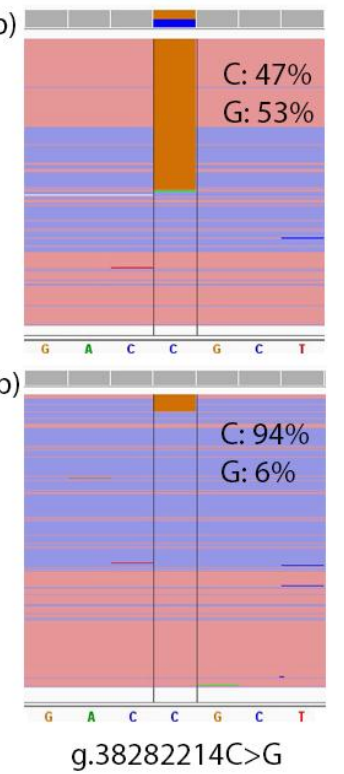
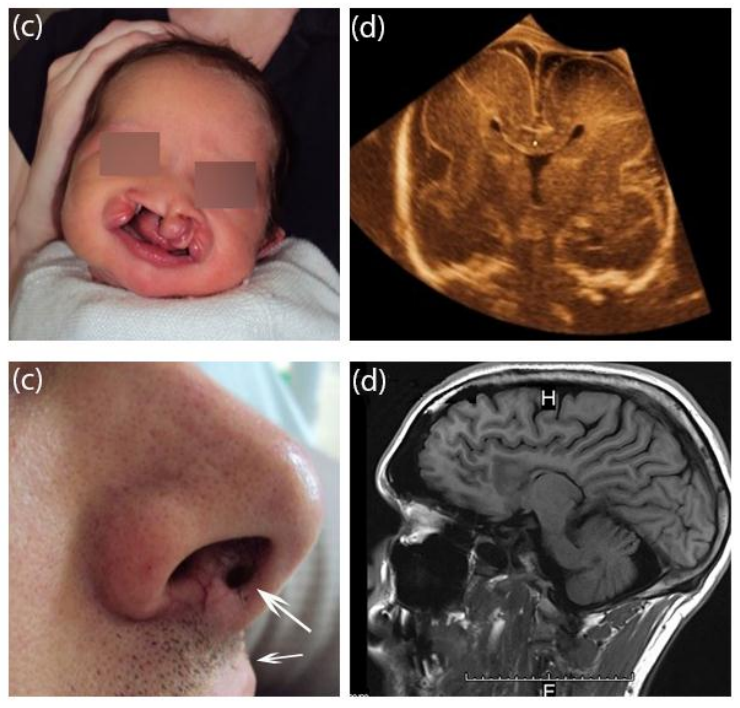

Table 1. Distribution of holoprosencephaly types and mutations in the cohort of 257 patients.

\begin{tabular}{|l|l|l|l|l|l|l|l|l|l|l|}
\hline Type & $\begin{array}{l}\text { All } \\
\text { (Male,Female) }\end{array}$ & SHH & ZIC2 & GLI2 & SIX3 & FGF8 & FGFR1 & DISP1 & DLL1 & SUFU \\
\hline Alobar & $62(24,38)$ & $9,7 \%$ & $8,1 \%$ & - & $6,5 \%$ & $1,6 \%$ & - & - & $1,6 \%$ & - \\
\hline Semilobar & $54(26,28)$ & $3,7 \%$ & $5,6 \%$ & - & $1,9 \%$ & $3,7 \%$ & $3,7 \%$ & - & $1,9 \%$ & - \\
\hline Lobar & $43(27,16)$ & $2,3 \%$ & $9,3 \%$ & $2,3 \%$ & $2,3 \%$ & $2,3 \%$ & $2,3 \%$ & $4,7 \%$ & - & - \\
\hline Syntelencephaly & $12(7,5)$ & $8,3 \%$ & - & - & $8,3 \%$ & $8,3 \%$ & - & - & - & - \\
\hline Microform & $80(42,38)$ & $6,3 \%$ & - & $8,8 \%$ & - & $1,3 \%$ & $1,3 \%$ & $1,3 \%$ & $1,3 \%$ & $1,3 \%$ \\
\hline Hartsfield & $3(3,0)$ & & & - & - & - & - & $66,7 \%$ & - & - \\
\hline Kallmann & $3(1,2)$ & - & - & - & - & - & - & - & - & - \\
\hline TOTAL & 257 & $5,8 \%$ & $4,7 \%$ & $3,1 \%$ & $2,7 \%$ & $2,3 \%$ & $2,3 \%$ & $1,2 \%$ & $1,2 \%$ & $0,4 \%$ \\
\hline & & & & & & & & & \\
\hline
\end{tabular}


Table 2. Characteristics of variants identified in GLI2, FGF8, FGFR1, DLL1, DISP1 and $S U F U$, and associated phenotypes.

\begin{tabular}{|c|c|c|c|c|c|c|c|}
\hline $\begin{array}{l}\text { Gen } \\
\text { e }\end{array}$ & $\begin{array}{l}\text { Variant } \\
\text { (gDNA) }\end{array}$ & $\begin{array}{l}\text { Variant } \\
\text { (cDNA) }\end{array}$ & $\begin{array}{l}\text { Variant } \\
\text { (protein) }\end{array}$ & $\begin{array}{l}\text { Deleteri } \\
\text { ous } \\
\text { score* } \\
\text { or effect }\end{array}$ & $\begin{array}{l}\text { Patient's } \\
\text { phenotype }\end{array}$ & Inheritance & $\begin{array}{l}\text { Paired } \\
\text { mutation }\end{array}$ \\
\hline \multirow[t]{6}{*}{ GLI2 } & $\begin{array}{l}\text { g.121708913G> } \\
\text { A }\end{array}$ & $\begin{array}{l}\text { c.349G> } \\
\text { A }\end{array}$ & p.Ala117Thr & $\begin{array}{l}\mathrm{D}: 2 \mathrm{P}: 1 \\
\mathrm{~T}: 7\end{array}$ & $\begin{array}{l}\text { hypopituitar } \\
\text { ism, } \\
\text { optic } \\
\text { atrophia / } \\
\text { bilateral } \\
\text { cleft }\end{array}$ & $\begin{array}{l}\text { father } \\
\text { (hypoteloris } \\
\text { m) }\end{array}$ & \\
\hline & $\begin{array}{l}\text { g.121712959dup } \\
\text { G }\end{array}$ & $\begin{array}{l}\text { c.596du } \\
\text { pG }\end{array}$ & $\begin{array}{l}\text { p.Ala200Argfs } \\
* 151\end{array}$ & $\begin{array}{l}\text { Frameshi } \\
\mathrm{ft}\end{array}$ & NPAS & mother & \\
\hline & g.121726436C>T & $\begin{array}{l}\text { c.790C> } \\
T\end{array}$ & p.Arg264* & Stop gain & $\mathrm{SMMCl}$ & mother & \\
\hline & $\begin{array}{l}\text { g.121743961del } \\
\text { C }\end{array}$ & $\begin{array}{l}\text { c. } 2064 d \\
\text { elC }\end{array}$ & $\begin{array}{l}\text { p.Ser690Alafs } \\
*_{5}\end{array}$ & $\begin{array}{l}\text { Frameshi } \\
\mathrm{ft}\end{array}$ & $\begin{array}{l}\text { hexadactyly } \\
\text {, choanal } \\
\text { atresia, } \\
\text { hypopituitar } \\
\text { ism, } \\
\text { cerebellar } \\
\text { atrophia }\end{array}$ & de novo & \\
\hline & $\begin{array}{l}\text { g.121744134G> } \\
\text { A }\end{array}$ & $\begin{array}{l}\text { c. } 2237 G \\
>A\end{array}$ & p.Trp746* & Stop gain & $\begin{array}{l}\text { lobar HPE, } \\
\text { premaxillary } \\
\text { agenesis, } \\
\text { pituitary } \\
\text { hamarthom } \\
\text { a, } \\
\text { hexadactyly }\end{array}$ & $\begin{array}{l}\text { not inherited } \\
\text { from the } \\
\text { mother }\end{array}$ & \\
\hline & $\begin{array}{l}\text { g.121748251G> } \\
\text { C }\end{array}$ & $\begin{array}{l}\text { c. } 4761 G \\
>C\end{array}$ & $\begin{array}{l}\text { p.*1587Tyrex } \\
t^{*} 46\end{array}$ & Stop loss & $\begin{array}{l}\text { hypopituitar } \\
\text { ism, } \\
\text { SMMCl, } \\
\text { choanal } \\
\text { atresia }\end{array}$ & mother & \\
\hline $\begin{array}{l}\text { FGF } \\
8\end{array}$ & $\begin{array}{l}\text { g.103534509G> } \\
T\end{array}$ & $\begin{array}{l}\text { c.317C> } \\
A\end{array}$ & p.Ala106Glu & $\begin{array}{l}\mathrm{D}: 9 \mathrm{P}: 0 \\
\mathrm{~T}: 1\end{array}$ & $\begin{array}{l}\text { semilobar } \\
\text { HPE }\end{array}$ & de novo & \\
\hline
\end{tabular}




\begin{tabular}{|c|c|c|c|c|c|c|c|}
\hline & $\begin{array}{l}\text { g.103531308G> } \\
\text { A }\end{array}$ & $\begin{array}{l}\text { c.356C> } \\
T\end{array}$ & p.Thr119Met & $\begin{array}{l}\mathrm{D}: 10 \mathrm{P}: 0 \\
\mathrm{~T}: 0\end{array}$ & $\begin{array}{l}\text { semilobar } \\
\text { HPE }\end{array}$ & ND & $\begin{array}{l}\text { FGFR1: } \\
\text { c. } 1977+1 G>A\end{array}$ \\
\hline & 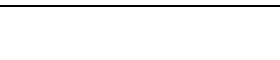 & \multirow[b]{2}{*}{$\begin{array}{l}\text { c. } 385 C> \\
T\end{array}$} & \multirow[b]{2}{*}{ p.Arg129* } & \multirow[b]{2}{*}{ Stop gain } & alobar HPE & father & \\
\hline & $\begin{array}{l}\text { g.103531279G> } \\
\text { A }\end{array}$ & & & & $\begin{array}{l}\text { syntelencep } \\
\text { haly }\end{array}$ & ND & \\
\hline & \multirow[t]{2}{*}{ g.103530204C>T } & \multirow[t]{2}{*}{$\begin{array}{l}\text { c.617G> } \\
\text { A }\end{array}$} & \multirow[t]{2}{*}{ p.Arg206GIn } & \multirow[t]{2}{*}{$\begin{array}{l}\mathrm{D}: 9 \mathrm{P}: 0 \\
\mathrm{~T}: 1\end{array}$} & $\begin{array}{l}\text { NPAS, } \\
\text { SMMCI, } \\
\text { hypoteloris } \\
\text { m }\end{array}$ & $\begin{array}{l}\text { mother } \\
\text { (hypoteloris } \\
\mathrm{m}, \\
\text { microretrogn } \\
\text { athism) }\end{array}$ & $\begin{array}{l}\text { DLL1: } \\
\text { p.Asp601_lle6 } \\
02 \\
\text { delinsVal }\end{array}$ \\
\hline & & & & & lobar HPE & ND & \\
\hline \multirow[t]{6}{*}{$\begin{array}{l}F G F \\
R 1\end{array}$} & g.38282214C>G & $\begin{array}{l}\text { c. } 749 G> \\
\text { C }\end{array}$ & p.Arg250Pro & $\begin{array}{l}\mathrm{D}: 8 \mathrm{P}: 0 \\
\mathrm{~T}: 2\end{array}$ & $\begin{array}{l}\text { lobar HPE, } \\
\text { cleft lip } \\
\text { palate }\end{array}$ & $\begin{array}{l}\text { father } \\
\text { (microform): } \\
\text { mosaicism } \\
6 \%\end{array}$ & \\
\hline & g. $38275486 C>A$ & $\begin{array}{l}\text { c. } 1454 G \\
>T\end{array}$ & p.Gly485Val & $\begin{array}{l}\mathrm{D}: 10 \mathrm{P}: 0 \\
\mathrm{~T}: 0\end{array}$ & $\begin{array}{l}\text { Hartsfield } \\
\text { syndrome }\end{array}$ & de novo & \\
\hline & g. $38275472 C>G$ & $\begin{array}{l}\text { c.1468G } \\
>C\end{array}$ & p.Gly490Arg & $\begin{array}{l}\text { D:10 P:0 } \\
T: 0\end{array}$ & $\begin{array}{l}\text { Hartsfield } \\
\text { syndrome }\end{array}$ & de novo & \\
\hline & g.38272346C>T & $\begin{array}{l}\text { c. } 1928 G \\
>A\end{array}$ & p.Gly643Asp & $\begin{array}{l}\mathrm{D}: 9 \mathrm{P}: 0 \\
\mathrm{~T}: 1\end{array}$ & $\begin{array}{l}\text { NPAS, } \\
\text { SMMCI, DI }\end{array}$ & de novo & \\
\hline & g.38272296C>T & $\begin{array}{l}\text { c. } 1977+ \\
1 G>A\end{array}$ & p.? & Splicing & $\begin{array}{l}\text { semilobar } \\
\text { HPE }\end{array}$ & ND & $\begin{array}{l}\text { FGF8: } \\
\text { p.Thr119Met }\end{array}$ \\
\hline & g.38271782C>T & $\begin{array}{l}\text { c. } 2074 G \\
>A\end{array}$ & p.Glu692Lys & $\begin{array}{l}\text { D:10 P:0 } \\
T: 0\end{array}$ & HPE, cleft & $\begin{array}{l}\text { mother } \\
\text { (hypogonado } \\
\text { tropic } \\
\text { hypogonadis } \\
\text { m) }\end{array}$ & \\
\hline \multirow[t]{2}{*}{ DLL1 } & \multirow[b]{2}{*}{$\begin{array}{l}\text { g.170592563_17 } \\
\text { 0592565del }\end{array}$} & \multirow[b]{2}{*}{$\begin{array}{l}\text { c.1802_ } \\
1804 \mathrm{del} \\
\text { ACA }\end{array}$} & \multirow[b]{2}{*}{$\begin{array}{l}\text { p.Asp601_lle } \\
602 \text { del } \\
\text { insVal }\end{array}$} & \multirow[b]{2}{*}{$\begin{array}{l}\text { Deletion } \\
\text { /insertio } \\
n\end{array}$} & $\begin{array}{l}\text { semilobar } \\
\text { HPE }\end{array}$ & father & \\
\hline & & & & & $\begin{array}{l}\text { NPAS, } \\
\text { SMMCl, } \\
\text { hypoteloris } \\
\text { m }\end{array}$ & $\begin{array}{l}\text { mother } \\
\text { (hypoteloris } \\
\mathrm{m}, \\
\text { microretrogn } \\
\text { athism) }\end{array}$ & $\begin{array}{l}\text { FGF8: } \\
\text { p.Arg206GIn }\end{array}$ \\
\hline
\end{tabular}




\begin{tabular}{|c|c|c|c|c|c|c|c|}
\hline & $\begin{array}{l}\text { g.170592125G> } \\
\text { A }\end{array}$ & $\begin{array}{l}\text { c. } 2117 \mathrm{C} \\
>T\end{array}$ & p.Ser706Leu & $\begin{array}{l}\mathrm{D}: 10 \mathrm{P}: 0 \\
\mathrm{~T}: 0\end{array}$ & alobar HPE & father & $\begin{array}{l}\text { SHH: } \\
\text { p.Leu386_Ala3 } \\
\text { 93del }\end{array}$ \\
\hline \multirow[t]{3}{*}{$\begin{array}{l}\text { DISP } \\
1\end{array}$} & $\begin{array}{l}\text { g.223175826A> } \\
\text { G }\end{array}$ & $\begin{array}{l}\text { c. } 1087 A \\
>G\end{array}$ & p.Asn363Asp & $\begin{array}{l}\mathrm{D}: 10 \mathrm{P}: 0 \\
\mathrm{~T}: 0\end{array}$ & \multirow{2}{*}{$\begin{array}{l}\text { lobar HPE, } \\
\text { hypoteloris } \\
\text { m }\end{array}$} & father & $\begin{array}{l}\text { DISP1: } \\
\text { p.Glu553Lys }\end{array}$ \\
\hline & $\begin{array}{l}\text { g.223176396G> } \\
\text { A }\end{array}$ & $\begin{array}{l}\text { c. } 1657 G \\
>A\end{array}$ & p.Glu553Lys & $\begin{array}{l}\mathrm{D}: 5 \mathrm{P}: 1 \\
\mathrm{~T}: 4\end{array}$ & & mother & $\begin{array}{l}\text { DISP1: } \\
\text { p.Asn363Asp }\end{array}$ \\
\hline & $\begin{array}{l}\text { g.223177637G> } \\
\text { A }\end{array}$ & $\begin{array}{l}\text { c. } 2898 \mathrm{G} \\
>\mathrm{A}\end{array}$ & p.Trp966* & Stop gain & $\begin{array}{l}\text { HPE } \\
\text { microform }\end{array}$ & ND & $\begin{array}{l}\text { SUFU: } \\
\text { p.Pro341Leu }\end{array}$ \\
\hline $\begin{array}{l}\text { SUF } \\
U\end{array}$ & g.104359301C>T & $\begin{array}{l}\text { c. } 1022 \mathrm{C} \\
>\mathrm{T}\end{array}$ & p.Pro341Leu & $\begin{array}{l}\mathrm{D}: 3 \mathrm{P}: 2 \\
\mathrm{~T}: 5\end{array}$ & $\begin{array}{l}\text { HPE } \\
\text { microform }\end{array}$ & ND & $\begin{array}{l}\text { DISP1: } \\
\text { p.Trp966* }\end{array}$ \\
\hline
\end{tabular}

The GenBank references used for nucleotide numbering were NM_005270.4 for GLI2, NM_033163.3 for FGF8, NM_023110.2 for FGFR1, NM_005618.3 for DLL1, NM_032890.3 for DISP1, NM_016169.3 for SUFU and NM_000193.2 for SHH. Nucleotide numbering uses +1 as the A of the ATG translation initiation codon in the reference sequence, with the initiation codon as codon 1 . The deleterious score was given by 10 predictions tools (SIFT, Polyphen2_HDIV, Polyphen2_HVAR, LRT, MutationTaster, MutationAssessor, FATHMM, CADD, MetaSVM and MetaLR).*: For detailed prediction data, see Suppl. Table S2. D, deleterious; P, possibly deleterious; T, tolerated; NPAS, nasal pyriform aperture stenosis; SMMCI, solitary median maxillary central incisor; ND: not determined. 